\title{
ROAD MORTALITY OF CARNIVORES (MAMMALIA, CARNIVORA) IN BELARUS
}

\author{
A. A. Sidorovich ${ }^{1}$, R. V. Novitsky ${ }^{2}$, I. A. Solovej ${ }^{3}$ \\ The Scientific and Practical Centre for Biological Resources, the NAS of Belarus, \\ Akademicheskaja st., 27, Minsk, 220072 Belarus \\ E-mail: 1Sidorovich.ecofox@gmail.com,2Nramphi@gmail.com,3Soloveji@tut.by
}

A. A. Sidorovich (https://orcid.org/0000-0001-7523-5048)
I. A. Solovej (https://orcid.org/0000-0002-6785-5089)

Road Mortality of Carnivores (Mammalia, Carnivora) in Belarus. Sidorovich, A. A., Novitsky, R. V., Solovej, I. A. - Global road infrastructure is expanding rapidly, and its threats to wildlife populations is increasing worldwide. We determined the species composition of carnivores killed on roads in Belarus. Seasonal dynamics and regional patterns of mortality rates were estimated. From July 2007 to August 2018 , we traveled a total of $52,159 \mathrm{~km}$, and recorded 368 carnivore road-kills representing 11 species $(73 \%$ of the study area checklist). Average mortality rate equaled 7.25 road-killed individuals per $1000 \mathrm{~km} /$ day surveyed across all roads. The most common species we encountered were the domestic cat, Felis catus Linnaeus, 1758 (53.3 \%, $\mathrm{n}=196)$, common dog, Canis familiaris Linnaeus, $1758(21.2 \%, \mathrm{n}=78)$, and red fox, Vulpes vulpes Linnaeus, $1758(14.7 \%, \mathrm{n}=54)$. Our results confirmed that traffic volume and time of the year strongly influence frequency of road-kills, along that, we did not reveal significant impacts of road mortality on populations of carnivores in Belarus.

Key words: Carnivora, road mortality, regional patterns, seasonal variation, Belarus.

\section{Introduction}

Mortality of animals on roads is one of the most recognized challenging problems in relation to biodiversity conservation. Road infrastructure is developed quite steadily and its impacts on wildlife, with time, can only increase (Hilty et al., 2006; Lodé, 2000; Corlatti et al., 2009; Stephen, Frissell, 2000; Barthelmess, 2014). Most studies of mammalian road mortality in 20th century were focused on ungulate road-kills because of its social and economic threats (Taylor, Goldingay, 2010). However, to date, there are a lot of published researches surveyed road-kills among other mammalian taxa, including carnivore 
species, in a view of biodiversity conservation (Corlatti et al., 2009; Červinka et al., 2015; and references therein). High levels of road mortality can reduce the abundance of animal populations in areas adjacent to a road. Although road mortality may be sustainable in abundant species with high reproductive rates, it can have a significant impact on populations of threatened or endangered species (e. g., Ferreras et. al., 1992; Kusak et. al., 2000; Stephen, Frisse, 2000; Corlatti et. al., 2009; Ceia-Hasse et al., 2017). For example, traffic mortality had significant impact and is considered a serious threat to populations of the Eurasian otter, Lutra lutra Linnaeus, 1758 in Germany (Hauer et al., 2002), the United Kingdom (Woodroffe, 1994) and Sweden (Seiler, 2003), Eurasian badger, Meles meles Linnaeus, 1758 in the United Kingdom (Clarke et al., 1998), brown bear, Ursus arctos Linnaeus, 1758 in Croatia (Kusak et al., 2000), and Florida panther, Puma concolor couguar Kerr, 1792 in United States (Evink et al., 1996). For endangered carnivore species with a small geographic range, road mortality can significantly contribute to their quick decline or population extinctions (e. g., Iberian lynx, Lynx pardinus Temminck, 1827 (Ferreras et al., 1992)). However, several studies on small mammals have noted no population declines in conditions of moderate road mortality (e. g., Clevenger et al., 2003; Lodé, 2000).

The highest collision risk may be related to the presence of specific habitat structures at the local spatial scale (Underhill, Angold, 2000; Grilo et al., 2009; Basille et al., 2013; Barthelmess, 2014). For example, the presence of linear habitats such as corridors or forest edges, which have been demonstrated to be viable elements for movements for several carnivore species, may increase road mortality risk (Clevenger et al., 2003; Hilty et al., 2006; Barthelmess, 2014; Červinka et al., 2015). Finally, another set of characteristics which may markedly affect road mortality risks represented by the road topography. For example, roads that are parallel to roadside vegetation were significantly associated with higher carnivore road mortality in contrast to raised or buried roads (Forman, Alexander, 1998; Glista et al., 2009; Červinka et al., 2015). Thus, to understand carnivore-vehicle patterns a comprehensive analysis of different factors on various spatial scales is needed.

In most cases, relative mortality (rather than absolute mortality) is used to reveal temporal and spatial effects and assess effectiveness of mitigation measures, whereas real impact of road collisions on local populations is hard to estimate. Counts of dead animals on roads almost always underestimate mortality (Slater, 2002; Teixeira et al., 2013).

The goal of this study is to identify and analyze the species composition and estimate mortality rates of carnivores on roads in Belarus. The effects of road mortality on native fauna have never been assessed in Belarus, and there is a single publication with preliminary results on a frequency of mammal road-kills on roads with different traffic intensity (Ghorov, Sidorovich, 2013).

\section{Material and methods}

Investigation of mortality rates of road-killed carnivores

The study has been carried out along the road network in Belarus which is represented by national highways (including the beltway around Minsk) and regional roads. Speed limits on regional roads were 90 $\mathrm{km} / \mathrm{h}$, national highways $100-120 \mathrm{~km} / \mathrm{h}$ and the beltway around Minsk $90-100 \mathrm{~km} / \mathrm{h}$. The daily traffic flow along regional roads was 2,000-5,000 vehicles, national highways $-5,000-10,000$ vehicles/day and the beltway around Minsk - more than 10,000 vehicles/day. Regional roads have two lanes of traffic, national highways have from two to four, and the beltway around Minsk has six lanes.

Hilly relief of the northern part Belarus originated from the last Menapian glaciation, and mostly plain relief on Central and Southern parts of Belarus saved after the earlier Elsterian glaciation. Northern and Central parts of Belarus belong to the coniferous-small-leaved European forest zone, whereas the Southern part is covered by broad-leaved forests. The climate is humid continental. Winters are variable with alternating periods of severe frosts below $-20^{\circ} \mathrm{C}$ and thaws lasting for some weeks. Usually snow cover persists for at least $1.5-2$ months, with a maximum depth of $30-90 \mathrm{~cm}$.

During 11 years (from July 2007 to august 2018) we carried out carnivores' road-kill detection surveys on selected routes on all national highways of Belarus (excluding residential areas of cities and towns). Although road-killed animals are frequently seen, actual rates of mortality can be very difficult to estimate accurately. A carcass of road-killed animal can be rapidly destroyed by vehicles in areas with high traffic, removed by scavengers or knocked off the road by vehicles.

To estimate precisely the mortality rate (the number of individuals killed per $1000 \mathrm{~km}$ of a route during a day, hereafter MR), we conducted surveys by sessions for several days with a daily check of the route in both directions. We have noticed that only small fragments of remnants remained on a road for more than 24 hours. Routes were driven at slow speeds $(<40 \mathrm{~km} / \mathrm{h})$ whenever possible to increase the probability of carcass detection while emphasizing surveyor safety. We fixed GPS coordinates of each road-killed animal with sub-meter resolution. A total length of survey routes comprised $52,159 \mathrm{~km}$. If a visual species detection was impossible, further identification was done in a laboratory by microscopic features of hair pile cross sections (Debrot et al., 1982; Teerink, 1991) and morphology of bone fragments (Pucek, 1981). 


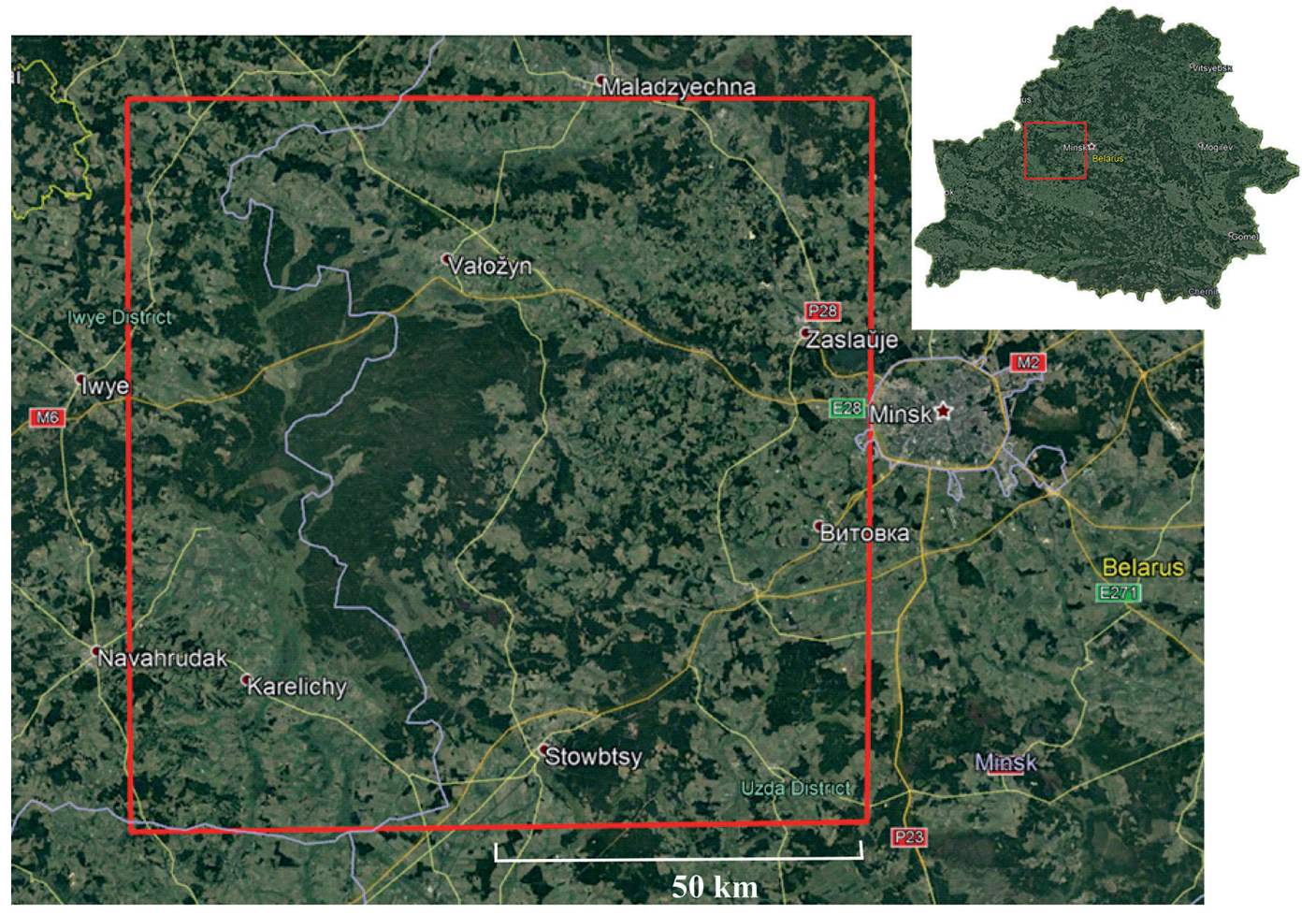

Fig. 1. The study area of $100 \times 100 \mathrm{~km}$ in Central Western Belarus.

Assessing impact of road mortality on population numbers of carnivores

To estimate the impact of road mortality on population numbers of carnivores, we performed more precise surveys of road-kills on all national highways and regional roads as well as did census of local population densities of carnivores in a square area of $100 \times 100 \mathrm{~km}$, i. e. in $10,000 \mathrm{~km}^{2}$ polygon (fig. 1). Inside this polygon we allocated a semi-natural forest landscape with a total area of $1,978 \mathrm{~km}^{2}$ and a rural-forest mosaic landscape with an area of $8,022 \mathrm{~km}^{2}$. The forest landscape (Valožyn and Stowbtsy districts of the Minsk Region; Iwye and Navahrudak districts of the Hrodna Region) is represented by a wide ranging woodland (the Naliboki Forest) of the boreal nemoral type. Various forest habitats give about $90 \%$. Large open grasslands on abandoned peateries spread through the forest. Rural-forest mosaic landscape (Minsk, Maladzyechna, Dzerzhinsk, Zaslawye, Stowbtsy, Uzda, and Valožyn districts of the Minsk Region; Iwye, Karelichy, and Navahrudak districts of the Hrodna Region) consists of alternating fragments of agricultural fields, pastures, human settlements, and patches of premature coniferous forests. There is a dense drainage canal network across whole its territory.

We conducted a census of population density only those carnivore species which were found dead on roads in the study area, i. e. the pine marten, Martes martes Linnaeus, 1758, stone marten, Martes foina Erxleben, 1777, red fox, Vulpes vulpes Linnaeus, 1758, the least weasel, Mustela nivalis Linnaeus, 1766, American mink, Neovison vison Schreber, 1777, Eurasian otter, European polecat, Mustela putorius Linnaeus, 1758, raccoon dog, Nyctereutes procyonoides Gray, 1834, and stray individuals of common dogs, Canis lupus familiaris Linnaeus, 1758. We did not estimate the population density of domestic cats, Felis silvestris catus Linnaeus, 1758 because there not any techniques allowing us to do this.

Riparian mustelids (the American mink, Eurasian otter and European polecat) were censused along various aquatic ecosystems during winter by searching the banks, shores and floodplains for tracks of the species. In winter, fresh tracks of individuals of the same species usually form concentrations in valley habitats separated by distances of variable length, where tracks of the species were either absent or only old tracks were found.

Similarly, but following a shuttle-shaped census route covering a particular plot of $1-2 \mathrm{~km}^{2}$, we counted track concentrations of the least weasel in the variety of habitats used by the species in early winter in conditions of little snow cover (up to $15 \mathrm{~cm}$ deep) one or two days since the last snowing. Such a track concentration was associated with presence of an individual of the species.

To estimate population densities of the pine marten, stone marten and red fox, we counted the species trails that crossed the established census route and calculated abundance index as number of trails per $1 \mathrm{~km}$ per day. Then we recalculated the abundance index into the population density with the Priklonsky formula (Priklonsky, 1965): 


\section{$\mathrm{P}=1.57 \times \mathrm{N} / \mathrm{H}$,}

where $\mathrm{P}-$ is the population density (individuals $/ 1 \mathrm{~km}^{2}$ );

1.57 - correction of Malyshev-Pereleshyn $(\pi / 2)$;

$\mathrm{N}$ - mean number of track trails counted per $1 \mathrm{~km}$ of a survey rout per a day;

$\mathrm{H}-$ mean daily movement distance of the species, $\mathrm{km}$.

The formula was adapted to the habitat conditions of North-Eastern Belarus by using estimates of the daily movement distance of the species in the conditions of different snow cover (Sidorovich, 2011). Daily movement distances of the species were assessed by combining snowtracking and radiotracking.

The population density of the raccoon dog was assessed by total inspection of an area in late winter and early spring, when raccoon dogs begin to be active in some degree at hibernation sites (such as badger setts and beaver burrows), but, nevertheless, they do not walk far away and mainly stay there. A census of stray dogs was also done by total visual inspection of an area. Additionally, we used information from 27 camera traps and questionnaire of local residents living in the area.

The percent of animals died out of the total population numbers was calculated as a measure of impact of road mortality on populations of carnivores by dividing the total number of road-killed animals (individuals) during a year within the study area on their population density and multiplying on 100 .

\section{Statistical analysis}

Variation in the data obtained was assessed by the coefficient of variation (hereafter $V \sigma$ ). One-way ANOVA $F$ were applied to reveal the differences in mortality rates of carnivores between highways and regional roads. To assess the difference between proportions of the species among road-kills and in the living community, the Ivlev's electivity index $D$ (after Jacobs, 1974) was calculated. The index can range from-1 (total avoidance of a species) through 0 (selection proportional to occurrence) to 1 (maximum positive selection). We applied the replicated goodness-of-fit $G$-test to reveal regional differences in species composition and proportions of different species among road-kills (Sokal, Rohlf, 1995). Calculations were performed using ASPID/GT software (Grigyantz, 1993).

\section{Results and discussion}

Species composition of road-killed carnivores and their mortality rates

In total, 368 separate remains of carnivores, representing 11 species, were sampled during the study period (table 1). Feral domestic cats comprised more than a half $(53.3 \%)$ of all road-killed carnivores (fig. 2). Mortality rates $(M R)$ of this species varied from 1.2 to 9.7 in different regions of Belarus. Also, the following three species were frequently found: the common dog $-21.4 \%(M R=0.0-6.4)$, red fox $-14.7 \%$ $(M R=0.0-1.5)$, stone marten $-5.4 \%(M R=0.0-0.8)$. Individuals of other species altogether constituted $5.4 \%$. The highest mortality rates of feral animals were reported on the beltway around Minsk, and highways in the Minsk Region. However, proportions of different species among total road-kills were almost the same in different regions $(G=2.4-$ $10.1 ; p>0.05)$. The highways with the highest occurrences of wild animals killed were that in Minsk and Hrodna Regions. The Eurasian badger was the only rare species found that have a conservation status in Belarus.

In seasonal relation, carnivores showed similar pattern of fatalities over the eleven years of monitoring. The number of road-killed animals showed pronounced seasonal variation. The highest occurrences of road-kills $(M R)$ were registered from the end of spring till midautumn (fig. 3), comprising from 6.8 to 30.3. Pronounced peak was in September, plausibly, due to dispersal of young individuals. During the rest seasons mortality rate did not exceed 3 individuals of all species together per $1000 \mathrm{~km} /$ day. Coefficient of variation $(V \sigma)$ of this parameter equaled $111.5 \%$.

\section{Effects of road mortality on population numbers of carnivores}

Using data on mortality rates and population density of carnivore species, we assessed the impact of road mortality on local populations of carnivores in a model study area (fig. 1). Data on absolute and relative road mortality rates of carnivores in Central Western Belarus are given in table 2. Within the area of $10,000 \mathrm{~km}^{2}, 244$ individuals of carnivores 
Table 1. Relative mortality rates of road-killed carnivores on highways in Belarus, 2007-2018. Overall total $=368$ road-kills per $52,159 \mathrm{~km}$ ( ${ }^{*}$ indicates species of special conservation concern in Belarus)

\begin{tabular}{|c|c|c|c|c|c|c|c|c|}
\hline \multirow[b]{2}{*}{ Species } & \multicolumn{7}{|c|}{ Mortality rates, individuals per $1000 \mathrm{~km} /$ day } & \multirow{2}{*}{$\begin{array}{l}\mathrm{V} \sigma \\
\%\end{array}$} \\
\hline & $\begin{array}{l}\text { Minsk } \\
\text { Region }\end{array}$ & $\begin{array}{c}\text { Beltway } \\
\text { around Minsk }\end{array}$ & \begin{tabular}{|l|} 
Hrodna \\
Region
\end{tabular} & $\begin{array}{l}\text { Vitsebsk } \\
\text { Region }\end{array}$ & $\begin{array}{l}\text { Homel } \\
\text { Region }\end{array}$ & $\begin{array}{c}\text { Brest } \\
\text { Region }\end{array}$ & $\begin{array}{c}\text { Mahilyow } \\
\text { Region }\end{array}$ & \\
\hline $\begin{array}{l}\text { Domestic cats } \\
\text { Felis silvestris catus } \\
(\mathrm{n}=196)\end{array}$ & 5.11 & 9.74 & 1.45 & 1.90 & 1.28 & 1.15 & 1.76 & 105.6 \\
\hline $\begin{array}{l}\text { Common dog } \\
\text { Canis lupus familiaris } \\
(\mathrm{n}=78)\end{array}$ & 1.57 & 6.37 & 0.83 & 0.47 & 0.21 & 0.66 & 0.00 & 153.8 \\
\hline $\begin{array}{l}\text { Red fox } \\
\text { Vulpes vulpes }(\mathrm{n}=54)\end{array}$ & 1.52 & 0.00 & 1.45 & 0.79 & 0.64 & 0.82 & 0.66 & 67.3 \\
\hline $\begin{array}{l}\text { Stone marten } \\
\text { Martes foina }(\mathrm{n}=20)\end{array}$ & 0.05 & 0.00 & 0.00 & 0.00 & 0.00 & 0.00 & 0.00 & 141.0 \\
\hline $\begin{array}{l}\text { Pine marten } \\
\text { Martes martes }(\mathrm{n}=3)\end{array}$ & 0.00 & 0.00 & 0.41 & 0.16 & 0.00 & 0.00 & 0.00 & 192.5 \\
\hline $\begin{array}{l}\text { European otter } \\
\text { Lutra lutra }(\mathrm{n}=1)\end{array}$ & 0.79 & 0.00 & 0.41 & 0.32 & 0.00 & 0.00 & 0.00 & 264.6 \\
\hline $\begin{array}{l}\text { Raccon dog } \\
\text { Nyctereutes } \\
\text { procyonoides }(\mathrm{n}=7)\end{array}$ & 0.05 & 0.00 & 0.41 & 0.16 & 0.00 & 0.33 & 0.22 & 129.0 \\
\hline $\begin{array}{l}\text { European polecat } \\
\text { Mustela putorius } \\
(\mathrm{n}=1)\end{array}$ & 0.00 & 0.00 & 0.21 & 0.00 & 0.00 & 0.00 & 0.00 & 264.6 \\
\hline $\begin{array}{l}\text { American mink } \\
\text { Neovison vison } \\
(\mathrm{n}=4)\end{array}$ & 0.05 & 0.00 & 0.41 & 0.16 & 0.00 & 0.00 & 0.00 & 173.3 \\
\hline $\begin{array}{l}\text { Least weasel } \\
\text { Mustela nivalis } \\
(\mathrm{n}=3)\end{array}$ & 0.15 & 0.00 & 0.00 & 0.00 & 0.00 & 0.00 & 0.00 & 264.6 \\
\hline $\begin{array}{l}{ }^{\star B a d g e r} \\
\text { Meles meles } \\
(\mathrm{n}=1)\end{array}$ & 0.00 & 0.00 & 0.00 & 0.00 & 0.00 & 0.00 & 0.22 & 267.7 \\
\hline All species together & 9.29 & 16.11 & 5.59 & 3.95 & 2.13 & 2.96 & 2.86 & 85.1 \\
\hline $\begin{array}{l}\text { Total length of census } \\
\text { routes, } \mathrm{km}\end{array}$ & 20350 & 5338 & 4830 & 6324 & 4686 & 6088 & 4543 & \\
\hline $\begin{array}{l}\text { Maximum speed } \\
\text { limit, } \mathrm{km} / \mathrm{h}\end{array}$ & $90-120$ & $90-100$ & $90-120$ & $90-120$ & $90-120$ & $90-120$ & $90-120$ & \\
\hline $\begin{array}{l}\text { Traffic intensity, } \\
\text { vehicles per a day }\end{array}$ & $\begin{array}{l}2000- \\
10000\end{array}$ & $\begin{array}{l}\text { More than } \\
10000\end{array}$ & $\begin{array}{l}2000- \\
5000\end{array}$ & $\begin{array}{c}2000- \\
5000\end{array}$ & $\begin{array}{c}2000- \\
5000\end{array}$ & $\begin{array}{c}2000- \\
5000\end{array}$ & $\begin{array}{c}2000- \\
5000\end{array}$ & \\
\hline
\end{tabular}

died every year on highways with intensive traffic rate, whereas only 10 individuals were killed on regional roads with a moderate traffic rate although the length of regional roads was higher in the study area. Reveale d differences in mortality rates of carnivores between highways and regional roads were statistically significant (One-way ANOVA $F=6.95$, $p<0.01)$. Impact of road mortality on different carnivore species was fairly low comprising from 0.01 to $4.56 \%$ of the population density.

Calculations did not reveal correlations between mortality rates and the species abundance in the living community. Ivlev's electivity index for most species was highly positive (the red fox, polecat, common dog, and pine marten; see table 2) or highly negative (the weasel, American mink, and raccoon dog).

\section{Conclusions}

Road-kill can pose serious threats to a variety of species. Vehicle traffic on roads can be a direct source of wildlife mortality and, in some instances, can be catastrophic (Ferreras et al., 1992; Fahrig, Rytwinski 2009; Lodé, 2000; Kusak et al., 2000; Taylor et 


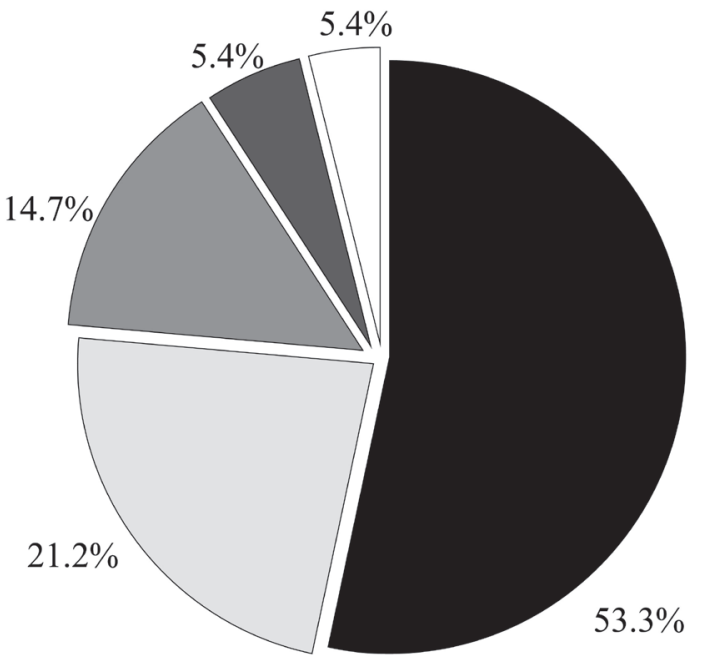

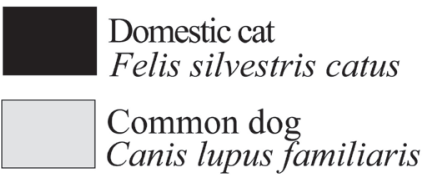

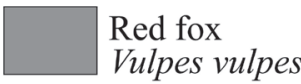

Stone marten

Martes foina

Other species

Fig. 2. The species composition of carnivorous mammals died on roads in Belarus, 2007-2018.

Table 2. Impact of road mortality on carnivore populations in Central-Western Belarus within model study area of $10,000 \mathrm{~km}^{2}$

\begin{tabular}{|c|c|c|c|c|c|c|c|c|}
\hline \multirow[t]{2}{*}{ Species } & \multicolumn{2}{|c|}{$\begin{array}{c}\text { Mortality rate, } \\
\text { ind. } \\
\text { per } 1000 \mathrm{~km} / \text { day }\end{array}$} & \multicolumn{2}{|c|}{$\begin{array}{l}\text { Total number } \\
\text { of road-killed } \\
\text { animals, } \\
\text { inds./year }\end{array}$} & \multirow[t]{2}{*}{$\begin{array}{l}\text { Population } \\
\text { density, } \\
\text { ind./100 km² }\end{array}$} & \multicolumn{2}{|c|}{$\begin{array}{c}\text { Percent of } \\
\text { animals died } \\
\text { out of the total } \\
\text { population } \\
\text { numbers }\end{array}$} & \multirow[t]{2}{*}{$\begin{array}{c}\text { Ivlev's } \\
\text { electivity } \\
\text { index (D) }\end{array}$} \\
\hline & $\begin{array}{l}\text { High- } \\
\text { ways }\end{array}$ & $\begin{array}{l}\text { Regional } \\
\text { roads }\end{array}$ & $\begin{array}{l}\text { High- } \\
\text { ways }\end{array}$ & $\begin{array}{c}\text { Regional } \\
\text { roads }\end{array}$ & & \begin{tabular}{c|} 
High- \\
ways
\end{tabular} & $\begin{array}{l}\text { Regional } \\
\text { roads }\end{array}$ & \\
\hline \multicolumn{9}{|c|}{$\begin{array}{c}\text { Semi-natural forest patch }\left(1,978 \mathrm{~km}^{2} \text {, total length of highways in the area }-52.5 \mathrm{~km} \text {, }\right. \\
\text { regional roads }-18.1 \mathrm{~km})\end{array}$} \\
\hline $\begin{array}{l}\text { Red fox } \\
\text { Vulpes vulpes }\end{array}$ & 0.78 & 0.02 & 14.95 & 0.13 & 16.7 & 4.52 & 0.04 & 0.84 \\
\hline $\begin{array}{l}\text { Pine marten } \\
\text { Martes martes }\end{array}$ & 0.62 & 0 & 11.88 & 0 & 48.4 & 1.24 & 0 & 0.43 \\
\hline $\begin{array}{l}\text { Least weasel } \\
\text { Mustela nivalis }\end{array}$ & 0.02 & 0 & 0.38 & 0 & 178.0 & 0.01 & 0 & -0.99 \\
\hline $\begin{array}{l}\text { European polecat } \\
\text { Mustela putorius }\end{array}$ & 0.34 & 0 & 6.52 & 0 & 8.3 & 3.97 & 0 & 0.77 \\
\hline $\begin{array}{l}\text { American mink } \\
\text { Neovison vison }\end{array}$ & 0.06 & 0 & 1.15 & 0 & 41.1 & 0.14 & 0 & -0.68 \\
\hline \multicolumn{9}{|c|}{$\begin{array}{c}\text { Rural-forest mosaic patch }\left(8,022 \mathrm{~km}^{2} \text {, total length of highways in the area }-136.5 \mathrm{~km} \text {, }\right. \\
\text { regional roads }-450.6 \mathrm{~km})\end{array}$} \\
\hline $\begin{array}{l}\text { Common dog } \\
\text { Canis lupus } \\
\text { familiaris }\end{array}$ & 1.61 & 0.01 & 80.21 & 1.64 & 55.6 & 1.80 & 0.04 & 0.48 \\
\hline $\begin{array}{l}\text { Red fox } \\
\text { Vulpes vulpes }\end{array}$ & 1.53 & 0.05 & 76.23 & 8.22 & 35.7 & 2.66 & 0.29 & 0.68 \\
\hline $\begin{array}{l}\text { Raccon dog } \\
\text { Nyctereutes } \\
\text { procyonoides }\end{array}$ & 0.02 & 0 & 1.0 & 0 & 20.5 & 0.06 & 0 & -0.86 \\
\hline $\begin{array}{l}\text { Stone marten } \\
\text { Martes foina }\end{array}$ & 0.89 & 0 & 44.34 & 0 & 49.7 & 1.11 & 0 & 0.17 \\
\hline $\begin{array}{l}\text { Least weasel } \\
\text { Mustela nivalis }\end{array}$ & 0.09 & 0 & 4.48 & 0 & 158.0 & 0.04 & 0 & -0.96 \\
\hline $\begin{array}{l}\text { American mink } \\
\text { Neovison vison }\end{array}$ & 0.06 & 0 & 2.99 & 0 & 14.9 & 0.25 & 0 & -0.61 \\
\hline $\begin{array}{l}\text { In total for the } \\
\text { whole study area }\end{array}$ & 6.02 & 0.08 & 244.13 & 9.99 & 626.9 & 0.39 & 0.02 & \\
\hline
\end{tabular}


al., 2002; Rytwinski, 2009; Benítez-López et al., 2010). For many species, road mortality can serve as a population limiting factor because their foraging and dispersal behaviors put them at risk of being struck on roadways. Although road mortality may not affect abundant populations, it can have a significant impact on populations of threatened or endangered species.

In our study, we did not reveal any significant impacts of road mortality on populations of carnivorous mammals in Belarus. The highest road mortality rates were attributable for abundant species with high reproduction rates (the red fox, common dog, polecat, and pine marten). Besides, their portion in the total road-kills was higher than their occurrence in the community. One of the possible explanations is that these species visited roads intentionally, plausibly searching for food (carcasses of dead animals, edible rubbish left after drivers). Some species (the weasel, American mink, and raccoon dog) avoided roads showing much lower mortality rates than their portion in the community.

Stray domestic cats and dogs constituted the bulk of road-killed carnivores. Their real population numbers in Belarus are still unknown and have not been estimated neither in urban nor in rural areas. So, it is hard to assess the contribution of road mortality to the overall mortality and population dynamics of stray mammals. The majority of investigations on road mortality of animals in different countries were focused on its consequences for wildlife. At the same time, stray dogs and cats are numerical species in rural landscapes with multiple impacts on ecosystem functioning (Crooks, Soulé, 1999). Thus, the rates of road mortality of stray animals and drivers affecting them is a challenging question for the future investigations.

The number of road-kills varied greatly in different seasons and areas (see fig. 3 and table 1). The bulk of dead carnivores was found from May till September during periods of reproduction and dispersal. Mortality of juvenile animals is usually higher comparing to adults due to the lack of stable behavioral patterns developed in adult animals. Similar results were obtained in many other countries (Waser, 1996; Grilo et al., 2009; Barthelmess, 2014). Also, it is clear from data presented in table 1 and 2 that a type of a road underpins mortality rates. Animals died more intensively on highways in Minsk surroundings where

individuals per $1000 \mathrm{~km} /$ day

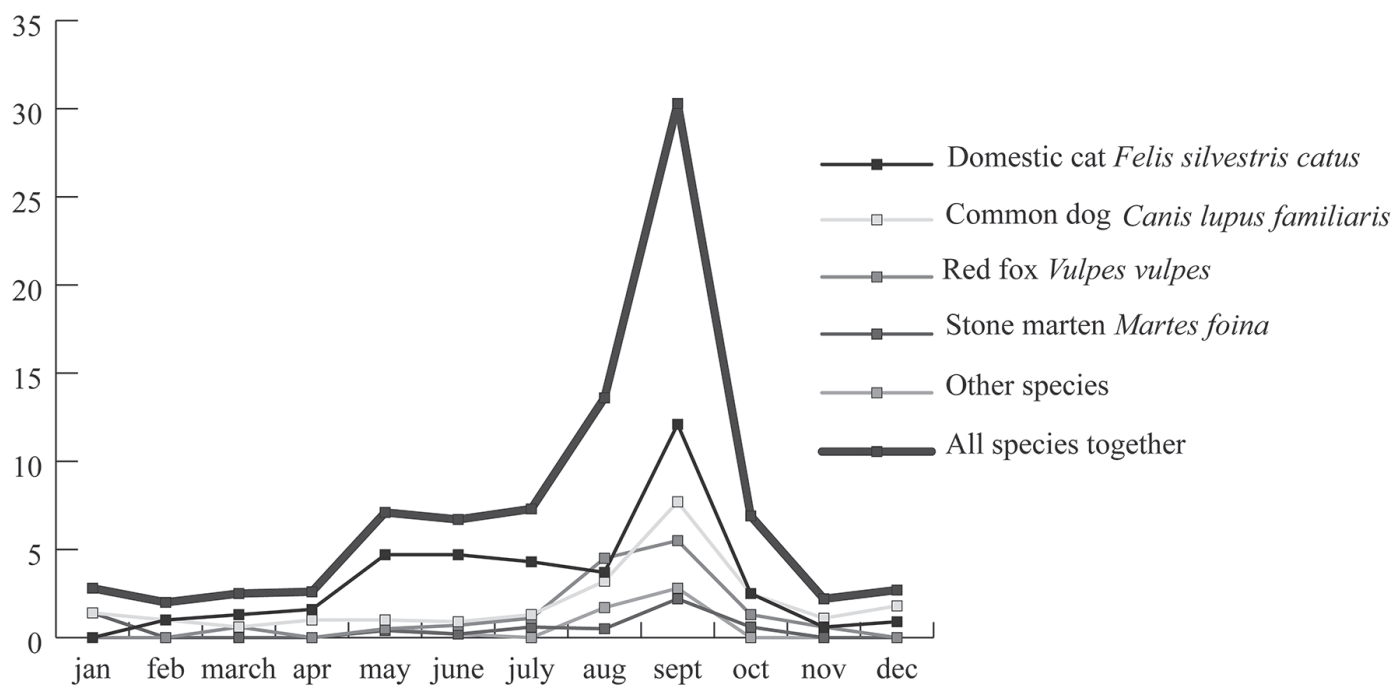

Fig. 3. Seasonal dynamics of mortality rates of carnivorous mammals on national highways in Belarus, 20072018. 
there is the most intensive traffic in the country. Low numbers of road-kills on regional roads also reflects the lower speeds and traffic volumes. Along that, we did not reveal any regional differences in species composition and proportions of different carnivore species among road-kills.

The only endangered species from the Red Data Book of Belarus found dead in this study was the European badger, though road accidents with the brown bear, Ursus arctos Linnaeus, 1758 (a one case) and the lynx, Lynx lynx Linnaeus, 1758 (two cases) were reported in mass media during the study period. Another large predator, the grey wolf, Canis lupus Linnaeus, 1758, was quite numerous in Belarus, however successfully escapes road accidents plausibly due to high wariness of the species.

Despite of relatively low impacts of the road mortality on populations of carnivorous mammals, another important factor to consider when developing road-kill mitigation systems is the connectivity of habitats (Yanes et al., 1995; Hilty et al., 2006). It is crucial for rare species with low population numbers. Fragmentation of their populations may result in difficulties to find a mate and negative isolation effects for genetic population structure. With expected expansion of the road network, many countries have made headway towards the solution of the problem: a record of the dead animals and campaigns to raise people's awareness about road impacts on wildlife are being carried out; the construction of transitions, tunnels, corridors for animals, installation of special signs and speed reducers are envisaged during a design stage of roads (Dodd et al., 2004; Sullivan, 2004; Jędrzejewski et al., 2006; Hilty et al., 2006; Barthelmess, 2014). Unfortunately, there is no the multipurpose decision for mitigating road-kill - what suits for one species may not be the best option for others. There are, however, various measures that may be successful for the areas with the high road mortality, such as underpasses or culvert and barrier wall systems (Clevenger, Waltho, 2000; Jackson, Griffin, 2000; Hilty et al., 2006; Glista et al., 2009; Grilo et al., 2010).

The authors are grateful to Zhorov Dmitrij, who helped with hard field works. The studies were financially supported by the Belarusian Republican Foundation for Fundamental Research (grant number 20131637) nd the Minskavtodor-Center (grant number 20150089).

\section{References}

Barthelmess, E. 2014. Spatial distribution of road-kills and factors influencing road mortality for mammals in Northern New York State. Biodiversity and Conservation, 23, 491-2514.

Basille, M., Van Moorter, B., Herfindal, I., Martin, J., Linnell, J. D. C., Odden, J., Andersen, R., Gaillard, J. M. 2013. Selecting habitat to survive: the impact of road density on survival in a large carnivore. PLoS One, 8, $1-11$.

Benítez-López, A., Alkemade, R., Verweij, P. A. 2010. The impacts of roads and other infrastructure on mammal and bird populations: a meta-analysis. Biological Conservation, 143, 1307-1316.

Ceia-Hasse, A., Borda-de-Agua, L., Grilo, C., Pereira, H. M. 2017. Global exposure of carnivores to roads. Global Ecology and Biogeography, 26, 592-600.

Červinka, J., Riegert, J., Grill, S., Šálek, M. 2015. Large-scale evaluation of carnivore road mortality: the effect of landscape and local scale characteristics. Mammal Research, 60, 233-243.

Clarke, G. P., White, P. C. L., Harris, S. 1998. Effects of roads on badger Meles meles populations in south-west England. Biological Conservation, 86, 117-124.

Clevenger, A. P., Chruszcz, B., Gunson, K. E. 2003. Spatial patterns and factors influencing small vertebrate fauna road-kill aggregations. Biological Conservation, 109, 15-26.

Clevenger, A. P., Waltho, N. 2000. Factors influencing the effectiveness of wildlife underpasses in Banff National Park, Alberta, Canada. Conservation Biology, 14, 47-56.

Corlatti, L., Hacklander, K., Frey-Roos, F. 2009. Ability of Wildlife Overpasses to Provide Connectivity and Prevent Genetic Isolation . Conservation Biology, 3 (23), 548-556.

Crooks, K. R., Soulé, M. E. 1999. Mesopredator release and avifauna extinctions in a fragmented system. Nature, 400, 563-566.

Debrot, S., Fivaz, G., Mermod, C., Weber, J. M. 1982. Atlas des poils de mammiferes d'Europe. Neuchatel. Inst. Zool. Univ. Neuchatel. 
Dodd, C. K. Jr., Barichivichm, W. J., Smith, L. L. 2004. Effectiveness of a barrier wall and culverts in reducing wildlife mortality on a heavily traveled highway in Florida. Biological Conservation, 118, 619-631.

Evink, G. L., Garrett, P., Zeigler, D., Berry, J., eds. 1996. Trends in addressing transportation related wildlife mortality. Florida. Florida Dept. of Transportation, Tallahassee, FL-ER-P, 58-96.

Fahrig, L., Rytwinski, T. 2009. Effect of roads on animal abundance: an empirical review and synthesis. Ecology and Society, 14, 21.

Ferreras, P., Aldama, J. J., Beltrán, J. F., Delibes, M. 1992. Rates and causes of mortality in a fragmented population of Iberian lynx Felis pardina Temminck 1824. Biological Conservation, 61, 197-202.

Forman, R. T. T., Alexander, L. E. 1998. Roads and their major ecological effects. Annual Review of Ecology and Systematics, 29, 207-231.

Ghorov, D. G., Sidorovich, A. A. 2013. Analysis of the species structure and mortality rates of mammals (Mammalia L.) dying on roads with different traffic intensities in Belarus. Vestnik Belorusskogo Gosudarstvennogo Universiteta, 3, 46-50.

Glista, D. J., DeVault, T. L., De Woody, J. A. 2009. A review of mitigation measures for reducing wildlife mortality on roadways. Landscape and Urban Planning, 91, 1-7.

Grigyantz, R. B. 1993. The software for informational and search systems with data bases of full-text documents of the heterogeneous structure (ASPID/GT) with applications for the statistical analysis (ECOPROG). The Academy of Sciences of Belarus, the Computing Center, Minsk.

Grilo, C., Bissonette, J. A., Santos-Reis, M. 2009. Spatial-temporal patterns in Mediterranean carnivore road casualties: consequences for mitigation. Biological Conservation, 142, 301-313.

Grilo, C., Bissonette, J. A., Cramer, P. C. 2010. Mitigation measures to reduce impacts on biodiversity. In: Jones, S. R., ed. Highways: Construction, Management, and Maintenance. Nova Science Publishers, Hauppauge, NY., 73-114.

Hauer, S., Ansorge, H., Zinke, O. 2002. Mortality patterns of otters (Lutra lutra) from eastern Germany. Journal of Zoology, 256 (3), 361-368.

Hilty, J. A., Lidicker, W. Z., Merenlender, A. M. 2006. Corridor ecology: the science and practice of linking landscapes for biodiversity conservation. Island Press, Washington DC.

Jackson, S. D., Griffin, C. R. 2000. A strategy for mitigating highway impacts on wildlife. In: Messmer, T. A. West, B., eds. Wildlife and Highways: Seeking Solutions to an Ecological and Socio-Economic Dilemma. Maryland. The Wildlife Society, Bethesda, 143-159.

Jacobs, J. 1974. Quantitative measurements of food selection; a modification of the forage ratio and Ivlev's electivity index. Oecologia, 14, 413-417.

Jędrzejewski, W., Nowak, S., Kurek, R., Mysłajek, R. W., Stachura, K., Zawadzka, B. 2006. Zwierzeta a drogi. Metody ograniczania negatywnego wplywu drog na populacje dzikich zwierza. Wydanie II poprawione i uzupelnione, Bialowieza, Zaklad Badania Ssakow PAN.

Kusak, J., Huber, D., Frkovic, A. 2000. The effects of traffic on large carnivore populations in Croatia. Biosphere Conservation, 3, 35-39.

Lodé, T. 2000. Effect of a Motorway on Mortality and Isolation of Wildlife Populations. Ambio, 29 (3), 163-166.

Priklonsky, S. G. 1965. Coefficients to treat the data of winter transsect method of census taking of game animals by their traces. Bull. MOIP (Moscow), biol. Seria, 70, 5-12 [In Russian].

Pucek, Zd., ed. 1981. Keys to Vertebrates of Poland Mammals. Mammal Research Institute Polish Academy of Sciences, Warsaw.

Seiler, A. 2003. The toll of the automobile: Wildlife and roads in Swede. Acta Universitatis Agriculturae Sueciae, Uppsala. Swedish University of Agricultural Sciences.

Sidorovich, V. E. 2011. Analysis of vertebrate predator-prey community. Tesey, Minsk.

Slater, F. M. 2002. An assessment of wildlife road casualties - the potential discrepancy between numbers counted and numbers killed. Web Ecology, 3, 33-42.

Sokal, R. R., Rohlf, F. J. 1995. Biometry: The Principles and Practice of Statistics in Biological Research. W. H. Freeman and company, New York.

Stephen, C., Frissell, Ch. A. 2000. Review of ecological effect of roads on terrestrial and aquatic communities. Conservation Biology, 14 (1), 18-30.

Sullivan, T. A. 2004. Effectiveness of temporary warning signs in reducing deer-vehicle collisions during mule deer migrations. Wildlife Society Bulletin, 32. 907-915.

Taylor, S. K., Buergelt, C. D., Roelke-Parker, M. E., Homer, B. L., Rotstein, D. S. 2002. Causes of mortality of free-ranging Florida panthers. Journal of Wildlife Diseases, 38, 107-114.

Taylor, S. K., Goldingay, R. L. 2010. Roads and wildlife: impacts, mitigation and implications for wildlife management in Australia. Wildlife Research, 37, 320-331.

Teerink, B. J. 1991. Hair of West-European Mammals. Cambridge Univ. Press, Cambridge.

Teixeira, F. Z., Coelho, A. V. P., Esperandio, I. B., Kindel, A. 2013. Vertebrate road mortality estimates: Effects of sampling methods and carcass removal. Biological Conservation, 157, $317-323$. 
Underhill, J. E., Angold, P. G. 2000. Effects of roads on wildlife in an intensively modified landscape. Environmental Reviews, 8, 21-39.

Waser, P. M. 1996. Patterns and consequences of dispersal in gregarious carnivores. In: Gittleman, J. L., ed. Carnivore Behaviour, Ecology and Evolution. Cornell University Press, Ithaca, NY.

Woodroffe, G. 1994. The otter. The Mammal Society.

Yanes, M., Velasco, J., Suarez, F. 1995. Permeability of roads and railways to vertebrates: the importance of culverts. Biological Conservation, 71, 217-222.

Received 8 January 2020

Accepted 24 April 2020 